\title{
Effect of a Transition Diet on Production Performance and Metabolism in Periparturient Dairy Cows
}

\author{
J. Guo, R. R. Peters, and R. A. Kohn ${ }^{1}$ \\ Department of Animal and Avian Sciences, University of Maryland, College Park 20742
}

\begin{abstract}
The objectives of this study were to characterize the change in blood metabolites over time, and to evaluate the effect of dietary energy concentration on ketone body accumulation in periparturient cows. Twentyeight multiparous Holstein cows were listed in order of their anticipated due dates and assigned randomly to 1 of 2 groups: with or without a transition diet. The control group received a nonlactating cow diet [1.54 $\mathrm{Mcal} / \mathrm{kg}$ of net energy for lactation $\left(\mathrm{NE}_{\mathrm{L}}\right), 10.9 \%$ crude protein $(\mathrm{CP}), 53.1 \%$ neutral detergent fiber (NDF)] from $28 \mathrm{~d}$ before expected parturition, and a lactation diet (1.77 Mcal of $\mathrm{NE}_{\mathrm{I}} / \mathrm{kg}, 16.8 \% \mathrm{CP}, 29.9 \% \mathrm{NDF}$ ) after parturition. The treatment group received a transition diet (1.71 Mcal of $\mathrm{NE}_{\mathrm{I}} / \mathrm{kg}, 16.8 \% \mathrm{CP}, 35.2 \% \mathrm{NDF}$ ) from 17 $\mathrm{d}$ before parturition to $14 \mathrm{~d}$ after calving and was fed the same diets as cows in the control group during the third week of lactation. Blood from the coccygeal vein was sampled 3 times per week from $21 \mathrm{~d}$ before expected parturition to $21 \mathrm{~d}$ postpartum for analysis of glucose, nonesterified fatty acids (NEFA), $\beta$-hydroxybutyrate, acetoacetate, acetone, and glycerol. There were no significant differences in dry matter intake, milk yield, milk components, body weight change, and body condition score change during the postcalving period. Plasma concentrations of different ketone bodies changed in parallel, stayed relatively constant precalving, peaked after parturition, and then decreased but remained high compared with concentrations late in gestation. Plasma concentrations of NEFA and glycerol changed in a pattern similar to those of the ketone bodies. Feeding a transition diet resulted in a greater area under the curve (AUC) for glucose in the last $17 \mathrm{~d}$ of gestation, but in no effect within the first $21 \mathrm{~d}$ in milk. Acetoacetate AUC was greater for treatment cows than for control cows across the first $21 \mathrm{~d}$ in milk. The AUC of NEFA and glycerol between $d 15$ and 21 postpartum were greater for treatment cows than for control cows.
\end{abstract}

Received May 1, 2007.

Accepted July 26, 2007.

${ }^{1}$ Corresponding author: rkohn@umd.edu
Feeding a transition diet both before and after parturition was associated with greater mobilization of adipose tissue and greater exposure to ketone bodies in early lactation compared with abruptly changing to a lactation diet after parturition.

Key words: periparturient cow, ketone body, glycerol

\section{INTRODUCTION}

Suboptimal transition from the late-gestation period to lactation can impair production and reproductive performance, and cause economic losses (Drackley, 1999; Overton and Waldron, 2004). The transition period is the most stressful time in the production cycle of a dairy cow because of depressed feed intake and endocrine and metabolic changes at parturition. The rapid increase in energy demands after parturition has resulted in recommendations for a greater energy density of diets for transition cows for 2 to $3 \mathrm{wk}$ before parturition (NRC, 2001). These energy demands were defined more specifically as being for carbohydrates (either fiber or starch) and are not satisfied by dietary fat (Overton and Waldron, 2004). In addition to the physiological changes associated with parturition, there may be additional effects of suddenly changing the diet on the day of parturition.

Optimal transition requires a comprehensive understanding of the biochemical events occurring during the periparturient period. Most of the available data describing the metabolism of dairy cows during transition are based on a few measurements obtained over a large interval of time, such as a week or longer. However, measurements of blood metabolites are associated with great variations, indicating large fluctuations in metabolite profiles during the periparturient period (Drackley, 1999). Measurements of blood metabolites should use more frequent sampling to capture the dynamic changes in the periparturient period. The objectives of this study were to characterize blood metabolite profiles during the transition period, and to evaluate the effects of abruptly changing the diet vs. maintaining the same diet before and after parturition. 
Table 1. Ingredient and nutrient composition of diets offered ${ }^{1}$

\begin{tabular}{lccc}
\hline & \multicolumn{3}{c}{ Diet } \\
\cline { 2 - 4 } Item & Nonlactating & Transition & Lactation \\
\hline Ingredient & \multicolumn{3}{c}{ of DM) } \\
\cline { 2 - 4 } Alfalfa-wheat silage & 41.9 & 23.4 & 24.9 \\
Timothy hay & 30.0 & - & - \\
Corn silage & 27.9 & 41.7 & 18.7 \\
Corn, high moisture & - & 16.7 & 37.5 \\
Soybean meal, 49\% CP & - & 7.5 & 7.5 \\
Soybean roasted & - & 6.7 & 6.7 \\
Salt and premix & $1.2^{2}$ & $4.0^{3}$ & $4.0^{2}$ \\
Chemical composition & & & \\
DM, as fed & 42.9 & 43.2 & 50.7 \\
NDF & 53.1 & 35.2 & 29.9 \\
ADF & 32.3 & 19.3 & 15.7 \\
Lignin & 5.5 & 4.2 & 2.4 \\
CP & 10.9 & 16.8 & 16.8 \\
NDF-CP & 0.26 & 0.28 & 0.27 \\
ADF-CP & 0.10 & 0.10 & 0.06 \\
Ether extract & 2.8 & 4.0 & 4.1 \\
Starch & 9.2 & 25.1 & 28.6 \\
Ash & 8.0 & 5.8 & 6.4 \\
NFC & 25.7 & 39.0 & 43.7 \\
NE ${ }^{7}$ & 1.54 & 1.71 & 1.77 \\
\hline
\end{tabular}

${ }^{1}$ Nonlactating diet (offered $28 \mathrm{~d}$ before expected calving), transition diet (offered $17 \mathrm{~d}$ before calving through 14 DIM for the treatment group), and lactation diet (offered after calving).

${ }^{2}$ Contained $23.8 \% \mathrm{CP}, 5.0 \% \mathrm{NaCl}, 1.7 \% \mathrm{P}, 4.7 \% \mathrm{Mg}, 0.05 \% \mathrm{~K}, 8$ $\mathrm{mg} / \mathrm{kg}$ of Se, $330 \mathrm{kU} / \mathrm{kg}$ of vitamin A, $82.6 \mathrm{kU} / \mathrm{kg}$ of vitamin $\mathrm{D}$, and $2.6 \mathrm{kU} / \mathrm{kg}$ of vitamin $\mathrm{E}$.

${ }^{3}$ Contained $29.84 \% \mathrm{CP}, 5.36 \% \mathrm{Ca}, 6.1 \% \mathrm{NaCl}, 0.9 \% \mathrm{P}, 2.1 \% \mathrm{Mg}$, $0.59 \% \mathrm{~K}, 5.25 \mathrm{mg} / \mathrm{kg}$ of Se, and $130 \mathrm{kU} / \mathrm{kg}$ of vitamin A.

${ }^{4}$ Neutral detergent-insoluble CP.

${ }^{5}$ Acid detergent-insoluble CP.

${ }^{6}$ Calculated by difference: $100-[(\mathrm{NDF}-\mathrm{NDF}-\mathrm{CP})+\mathrm{CP}+$ ether extract + ash].

${ }^{7}$ Calculated according to the NRC (2001).

\section{MATERIALS AND METHODS}

\section{Cows, Diets, and Treatments}

The experiment was conducted at the University of Maryland Central Research Farm in Clarksville, Maryland, from August 22, 2004 to January 15, 2005. All procedures with animals were reviewed and approved by the University of Maryland Animal Care and Use Committee. Twenty-eight multiparous Holstein cows were blocked according to parity and expected calving date and assigned at random to 1 of 2 groups: treatment or control. From $28 \mathrm{~d}$ before expected calving, animals were fed a nonlactating cow diet (Table 1) for $14 \mathrm{~d}$. Onehalf of the cows remained on the nonlactating cow diet as the control group, and the other half were fed a transition diet (Table 1) until $14 \mathrm{~d}$ after calving as the treatment group. A lactation diet was offered to control cows after calving and to treatment cows $14 \mathrm{~d}$ after calving. All cows were fed ad libitum and individually throughout the experiment. Thus, cows assigned the transition treatment continued to receive the diet with intermediate energy density after parturition for $2 \mathrm{wk}$, which is not a recommended practice for commercial herds.

\section{Measurements}

Cows were tied in individual stalls. Diets were offered ad libitum once daily in the morning as TMR. The amount of TMR offered and refused was measured daily for each cow. Feed intake was obtained by subtracting feed refused from feed offered. Samples of diets were obtained on Monday, Wednesday, and Friday throughout the trial, dried at $55^{\circ} \mathrm{C}$ for $120 \mathrm{~h}$, ground through a Wiley mill (1-mm screen; Arthur H. Thomas, Philadelphia, PA), composited weekly, and analyzed for starch (AOAC, 1990) by using a commercially available kit (STA-20, Sigma Chemical Co.), and sequentially analyzed for NDF, ADF, and lignin (Mertens, 2002), ash $\left(550^{\circ} \mathrm{C}\right.$ for $\left.24 \mathrm{~h}\right)$, neutral detergent-insoluble $\mathrm{CP}$, acid detergent-insoluble CP (Licitra et al., 1996), and CP (AOAC, 1990) on a DM basis. The nonlactating cows were weighed before feeding, and the lactating cows were weighed after the morning milking on Monday, Wednesday, and Friday. Body condition score was assessed by 2 individuals on Wednesdays on a 5 -point scale $(1=$ thin to $5=$ fat $)$ at 0.25 -unit increments $(E d-$ monson et al., 1989). Calf weights were recorded before the first colostrum was fed.

Cows were milked twice daily, and milk production was recorded at each milking. Morning and evening milk samples were obtained on Monday, Wednesday, and Friday, and analyzed by Lancaster DHIA (Manheim, PA) by using automated wet chemistry procedures for fat, protein, and TS (model 300, Bentley Instruments, Chaska, MN) and for MUN (Chemspec 150, Bentley Instruments). Lactose was analyzed in our laboratory (Bergmeyer et al., 1983).

Blood samples were collected by puncture of the coccygeal vein with 20 -gauge needles and Vacutainer tubes containing sodium fluoride (Becton Dickinson, Franklin Lakes, $\mathrm{NJ}$ ) before and at $3.5 \mathrm{~h}$ after the morning feeding on Monday, Wednesday, and Friday. To compare the coccygeal vein sampling regimen, the first 22 cows entering the study were fitted with a sterile jugular catheter $(0.04 \mathrm{~cm}$ i.d. and $0.08 \mathrm{~cm}$ o.d.) on the Thursday between 5 and 12 DIM; patency was maintained by $3.6 \%$ citrate in physiological saline solution. On the next day, $5 \mathrm{~mL}$ of jugular blood was collected hourly from 0700 to $1900 \mathrm{~h}$ into Vacutainer tubes containing sodium fluoride (Becton Dickinson). Samples were immediately placed on ice, and within 30 min were centrifuged at $1,000 \times g$ for $10 \mathrm{~min}$. Plasma was stored on dry ice and transported to the laboratory within $9 \mathrm{~h}$. Upon arrival, plasma samples were analyzed for aceto- 
acetate (ACAC; Harano et al., 1983). Acetone was determined by gas chromatography (model 6890; Agilent Technologies Inc., Wilmington, DE) in a 2-mm glass column packed with Carbopack 1176 (Supelco Inc., Bellefonte, PA). Helium was used as the carrier gas at a flow rate of $20.0 \mathrm{~mL} / \mathrm{min}$, and the injector, column, and detector temperatures were 220,60 , and $200^{\circ} \mathrm{C}$, respectively. Plasma was deproteinized with $15 \%$ perchloric acid (1:1, ratio of plasma to acid). The supernatant was mixed with $2 M$ tribasic phosphate buffer (4:1 ratio of supernatant to buffer). The standard for acetone analysis was prepared according to method 973.69 of AOAC (2000). The rest of the split samples were stored at $-25^{\circ} \mathrm{C}$ until later analyses for NEFA (Johnson and Peters, 1993), glucose (Raabo and Terkildsen, 1960; using the commercially available kit 510, Sigma Chemical Co.), glycerol (Foster et al., 1978; using the commercially available kit GY105, Randox, San Diego, CA) and BHBA (Harano et al., 1983). The intraassay coefficient of variation was less than $5 \%$.

\section{Statistical Analyses}

The effects of days receiving the transition diet prepartum and pretreatment BW and BCS initially were analyzed as covariates, and the effects of expected due dates and parity initially were analyzed as block factors. The covariates were not significant and were subsequently excluded from the final model. The measurements were analyzed by ANOVA by using PROC MIXED (SAS Institute, 1999). The statistical model was:

$$
\mathrm{Y}_{\mathrm{ijk}}=u+\mathrm{B}_{\mathrm{h}}+\mathrm{P}_{\mathrm{i}}+\mathrm{T}_{\mathrm{j}}+\mathrm{C}_{\mathrm{k}(\mathrm{j})}+\mathrm{P}_{\mathrm{i}} \times \mathrm{T}_{\mathrm{j}}+\varepsilon_{\mathrm{hijk}},
$$

where $\mathrm{Y}_{\mathrm{ijk}}$ is the observations for dependent variables; $u$ is the overall mean; $\mathrm{B}_{\mathrm{h}}$ is the block effect of expected due date and parity; $P_{i}$ is the effect of time (the last 17 $\mathrm{d}$ of gestation, the first $14 \mathrm{DIM}$, and from d 15 to $\mathrm{d} 21$ postpartum); $\mathrm{T}_{\mathrm{j}}$ is the effect of treatment; $\mathrm{C}_{\mathrm{k}(\mathrm{j})}$ is the random effect of cow within treatment; $P_{i} \times T_{j}$ is the interaction between time and treatment; and $\varepsilon_{\mathrm{ijk}}$ is the residual error. The covariance between residuals within cow was modeled as compound symmetry determined by goodness-of-fit measures. Significance was declared at $P<0.05$, unless otherwise noted.

The concentrations of coccygeal blood metabolites before and after the morning feeding within a day were averaged to reduce daily variation. Area under the curve (AUC) over the entire sampling period for blood metabolites was calculated by using the trapezoidal rule (Jones, 1997).

Agreement of sampling regimens between the coccygeal and jugular veins was examined by using the statis- tical procedures of Bland and Altman (1986). The differences between blood samples drawn from the jugular and coccygeal veins at the same time were calculated, and the standard deviation of the differences was used to measure random fluctuations about this mean. The 95\% limits of agreement were calculated as the mean difference \pm 1.96 times the standard deviation of the differences. The 2 sampling regimens were considered as not significantly different if the difference between the average concentrations of blood metabolites before and after the morning feeding from the coccygeal vein and the average concentrations across the first $12 \mathrm{~h}$ after the morning feeding from the jugular vein were within the $95 \%$ limit of agreement. This analysis guards against type II error to determine the limits of substituting one analysis for another.

\section{RESULTS}

\section{Composition of Diets}

Ingredient and chemical compositions of the diets are presented in Table 1 . The energy values of the diets were calculated to be $1.54,1.71$, and $1.77 \mathrm{Mcal}$ of $\mathrm{NE}_{\mathrm{L}} /$ $\mathrm{kg}$ for the nonlactating, transition, and lactation diets, considering the discount factors based on total digestible nutrients intake above maintenance requirements (NRC, 2001). The differences in energy densities between the transition and lactation diets resulted from different high-moisture corn and corn silage contents in the 2 diets. Likewise, NFC and starch contents were greater in the lactation diet compared with the transition diet. All the other nutrients were consumed in quantities sufficient to meet NRC requirements (2001).

\section{Health and Calf Weight}

Thirty cows were initially selected for the trial, but 2 cows from the treatment group failed to complete the trial. One cow on the transition diet was diagnosed with clinical ketosis at $\mathrm{d} 2$ after calving and was administered i.v. 1,000 cc of 5\% dextrose on d 2 and 3 postpartum. Another cow received the transition diet for only $3 \mathrm{~d}$ before calving, and delivered twin calves. Unfortunately, data from the ketotic cow could not be collected during the critical time points when ketosis was evident. Data from this ketotic cow and the one that calved early were not included in the statistical analysis. The incidence of other health problems for each treatment could not be statistically analyzed in a trial of this size. Calf weights at birth were not affected by the transition $\operatorname{diet}(P=0.53)$. 
Table 2. Effect of a transition diet from $17 \mathrm{~d}$ before calving through 14 DIM on DMI, BW, BCS, and energy balance

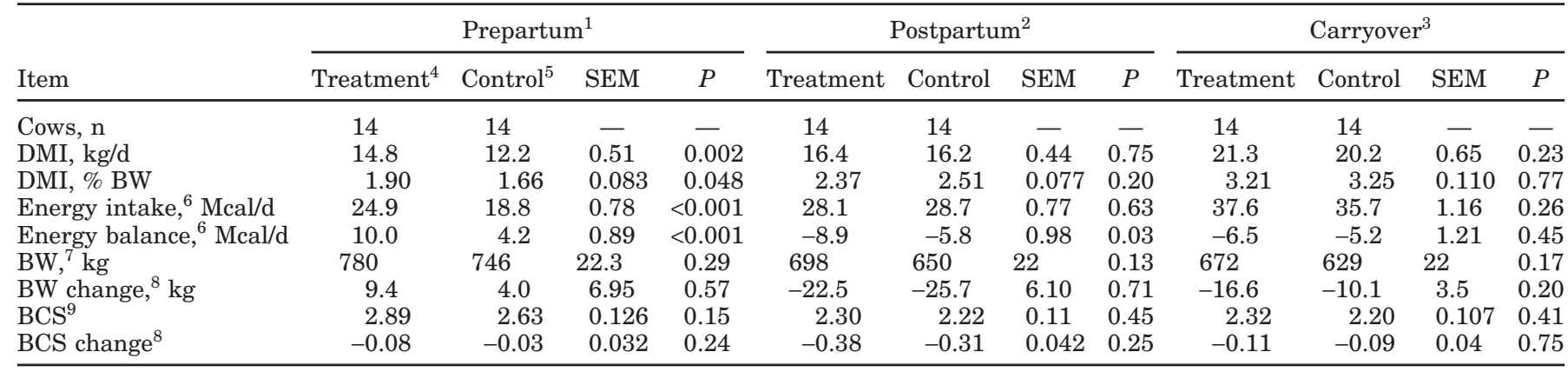

${ }^{1}$ Last $17 \mathrm{~d}$ of the gestation period.

${ }^{2}$ First $14 \mathrm{~d}$ of the lactation period.

${ }^{3}$ From d 15 to 21 of the lactation period.

${ }^{4}$ Treatment cows were offered a transition diet in the last $17 \mathrm{~d}$ of gestation and the first $14 \mathrm{~d}$ of lactation, and a lactation diet from $\mathrm{d} 15$ to 21 of lactation.

${ }^{5}$ Control cows were offered a nonlactating cow diet in the last $17 \mathrm{~d}$ of gestation, and a lactation diet in the first 21 DIM.

${ }^{6}$ Calculated according to the NRC (2001).

${ }^{7}$ Prepartum = mean BW from $3 \mathrm{wk}$ precalving to calving; postpartum = mean BW from calving to 2 wk postcalving; carryover = mean $\mathrm{BW}$ in the third week of lactation.

${ }^{8}$ Prepartum = difference between pretreatment and calving data; postpartum = difference between calving data and data at $2 \mathrm{wk}$ postcalving; carryover $=$ difference between data at $2 \mathrm{wk}$ postcalving and data at $3 \mathrm{wk}$ postcalving.

${ }^{9} \mathrm{BCS}$ : 1 = thin, 5 = fat. Prepartum = mean BCS at $3 \mathrm{wk}$ precalving; postpartum = mean BCS at 2 wk postcalving; carryover = mean BCS at 3 wk postcalving.

\section{DMI, BW, BCS, and Energy Balance}

The average length of time cows consumed the transition diet before calving was $17 \mathrm{~d}$ (minimum $=12 \mathrm{~d}$; maximum $=26 \mathrm{~d}$ ). Thus, data from the last $17 \mathrm{~d}$ of gestation were used to determine prepartum treatment effects. Using the last $12 \mathrm{~d}$ of gestation (minimum time on the transition diet) resulted in the same statistical conclusions (data not shown). Precalving DMI was greater for the treatment group compared with the control group $(P=0.002$; Table 2 and Figure 1). Postcalving

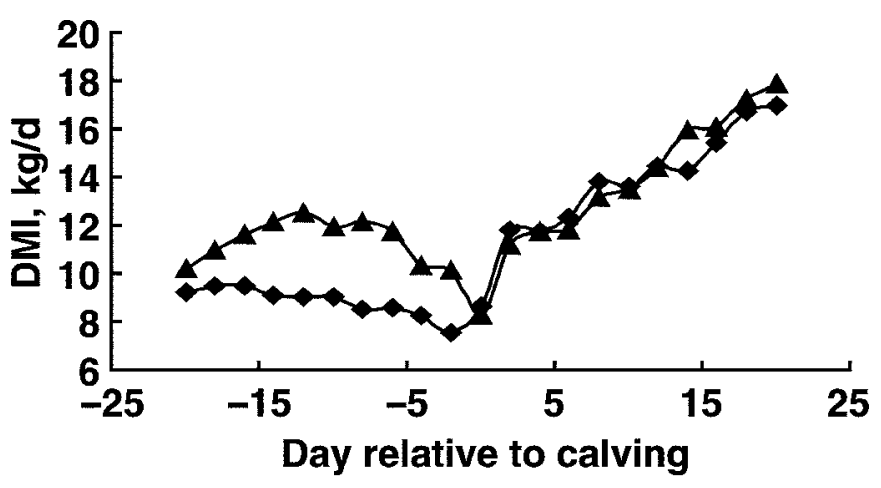

Figure 1. Dry matter intake around the time of calving (pooled $\mathrm{SEM}=1.41$ ) for cows fed a nonlactating diet prepartum and a lactation diet postpartum (control, $\diamond$ ), or a transition diet from $17 \mathrm{~d}$ prior to calving through 14 DIM (treatment, $\boldsymbol{\Delta}$ ). Each dot represents the average of 2 contiguous days. The treatment group had greater DMI in the last $17 \mathrm{~d}$ of gestation than the control group $(P=0.002)$.
DMI did not differ between the treatment and control groups while cows were on the treatment in the first 14 DIM $(P=0.44)$ and after the treatment from $d 15$ to 21 of lactation $(P=0.23)$. Likewise, animals fed the transition diet had greater energy intake during the prepartum period compared with animals in the control group ( 24.9 vs. $18.8 \mathrm{Mcal} / \mathrm{d} ; P<0.01)$, but there was no difference postcalving $(P>0.10)$. All the cows were in positive energy balance before calving and in negative energy balance after calving (Figure 2). The treatment cows had a greater energy balance prepartum (10.0 vs. $4.2 \mathrm{Mcal} / \mathrm{d} ; P<0.01)$ and a lower negative energy balance in the first $14 \mathrm{DIM}(-8.9 \mathrm{vs} .-5.8 \mathrm{Mcal} / \mathrm{d} ; P=0.03)$.

Initial BW and BCS were similar between the treatment and control groups $[P>0.10 ; 758(\mathrm{SE}=16.2)$ $\mathrm{kg}$, and $2.76(\mathrm{SE}=0.126)$, respectively]. The observed changes of BCS and BW were typical changes in the herd. No treatment effect was observed for changes in BW and BCS throughout the trial $(P>0.15$; Table 2$)$.

\section{Milk Yield and Composition}

In the previous lactation, the 305-d mature-equivalent milk yields and fat and protein percentages did not differ between the 2 groups $(P>0.10)$, and were $11,577(\mathrm{SE}=381) \mathrm{kg}, 3.92 \%(\mathrm{SE}=0.08)$, and $2.98 \%$ $(\mathrm{SE}=0.03)$, respectively. No treatment effect was found for milk yield or milk components in the first 21 DIM $(P>0.05$; Table 3$)$. The patterns of milk yield were 


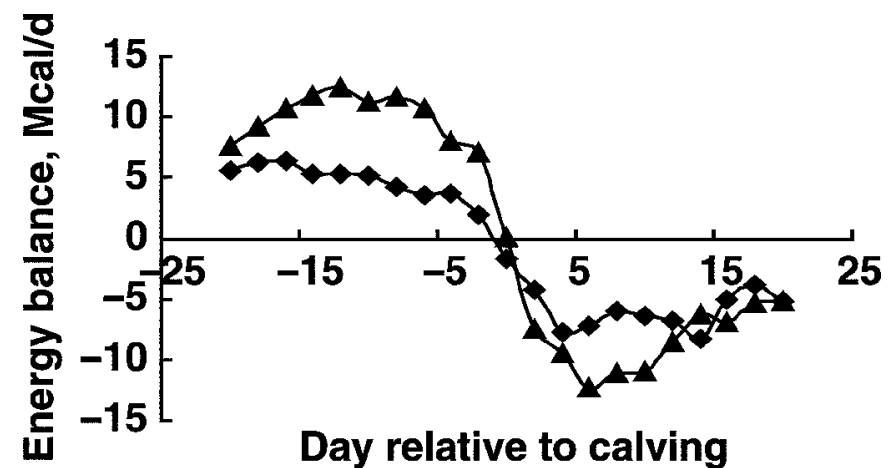

Figure 2. Energy balance around the time of calving (pooled SEM = 1.60) for cows fed a nonlactating diet prepartum and a lactation diet postpartum (control, $\downarrow$ ), or a transition diet from $17 \mathrm{~d}$ prior to calving through 14 DIM (treatment, $\mathbf{\Delta}$ ). Each dot represents the average of 2 contiguous days. Energy balance was calculated according to the NRC (2001). Treatment cows had a greater energy balance in the last $17 \mathrm{~d}$ of gestation $(10.0 \mathrm{vs} .4 .2 \mathrm{Mcal} / \mathrm{d} ; P<0.01)$, and a lower negative energy balance in the first 14 DIM ( -8.9 vs. $-5.8 \mathrm{Mcal} / \mathrm{d} ; P=0.03$ ) than control cows.

similar between the treatment and control groups (Figure 3$)$.

\section{Blood Metabolites}

Plasma concentrations of glucose, NEFA, glycerol, $\mathrm{ACAC}, \mathrm{BHBA}$, and acetone at 0 and $3.5 \mathrm{~h}$ after the morning feeding from the coccygeal vein, and at each hour within $12 \mathrm{~h}$ postprandial from the jugular vein are presented in Figure 4. The average concentrations of acetone at 0 and $3.5 \mathrm{~h}$ after the morning feeding from

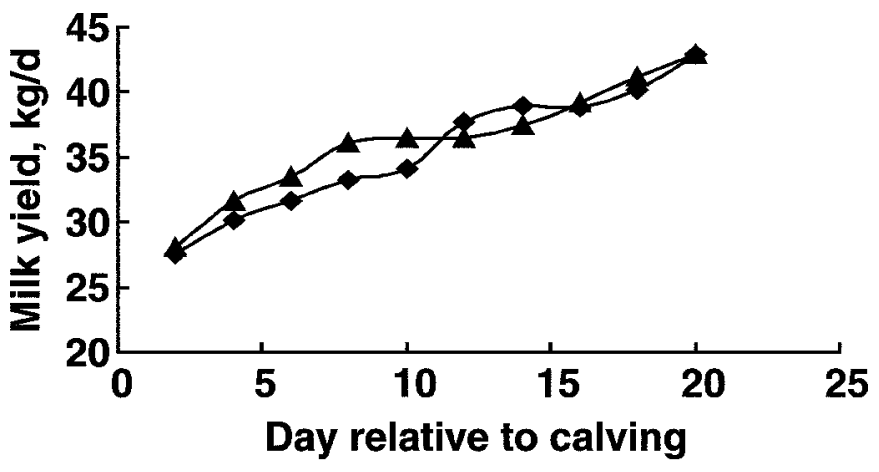

Figure 3. Milk yield during the first 21 DIM (pooled SEM = 1.2) for cows fed a nonlactating diet prepartum and a lactation diet postpartum (control, $\bullet$ ), or a transition diet from $17 \mathrm{~d}$ prior to calving through 14 DIM (treatment, $\mathbf{\Delta}$ ). Each dot represents the average of 2 contiguous days.

the coccygeal vein were different from the averages at each hour within $12 \mathrm{~h}$ postprandial from the jugular vein $(P<0.05)$. The averages of ACAC were also different between tail and jugular vein plasma samples $(P<$ 0.05). The differences between jugular and coccygeal vein blood drawn at the same time are presented in Table 4.

The glucose concentration profiles in the control and treatment groups are shown in Figure 5. In both groups, plasma glucose concentrations increased at calving and then dropped dramatically after calving. During the last $17 \mathrm{~d}$ of gestation, AUC for glucose in the treatment group was greater than that in the control group $(P<$ 0.05; Table 5).

Table 3. Effect of a transition diet from $17 \mathrm{~d}$ before calving through 14 DIM on calf weight, milk yield, and milk composition

\begin{tabular}{|c|c|c|c|c|c|c|c|c|}
\hline \multirow[b]{2}{*}{ Item } & \multicolumn{4}{|c|}{ Postpartum ${ }^{1}$} & \multicolumn{4}{|c|}{ Carryover $^{2}$} \\
\hline & Treatment $^{3}$ & Control $^{4}$ & SEM & $P$ & Treatment & Control & SEM & $P$ \\
\hline Cows, $\mathrm{n}$ & 14 & 14 & - & - & 14 & 14 & - & - \\
\hline Calf weight, kg & 44.6 & 43.5 & 1.26 & 0.53 & - & - & - & - \\
\hline Milk yield, $\mathrm{kg} / \mathrm{d}$ & 33.4 & 32.9 & 1.4 & 0.79 & 41.1 & 40.3 & 1.4 & 0.68 \\
\hline $4 \%$ FCM, kg/d & 37.2 & 34.5 & 1.5 & 0.21 & 41.7 & 39.0 & 1.6 & 0.25 \\
\hline Fat, $\%$ & 4.54 & 4.33 & 0.11 & 0.20 & 4.06 & 3.82 & 0.17 & 0.33 \\
\hline Fat, kg/d & 1.57 & 1.43 & 0.07 & 0.17 & 1.69 & 1.53 & 0.08 & 0.19 \\
\hline Protein, \% & 3.70 & 3.49 & 0.11 & 0.13 & 2.94 & 2.87 & 0.06 & 0.39 \\
\hline Protein, kg/d & 1.27 & 1.15 & 0.05 & 0.10 & 1.20 & 1.15 & 0.04 & 0.50 \\
\hline Lactose, $\%$ & 4.24 & 4.16 & 0.05 & 0.31 & 4.48 & 4.31 & 0.07 & 0.11 \\
\hline Lactose, $\mathrm{kg} / \mathrm{d}$ & 1.47 & 1.37 & 0.06 & 0.23 & 1.85 & 1.74 & 0.07 & 0.31 \\
\hline SNF, \% & 5.33 & 5.32 & 0.05 & 0.93 & 5.68 & 5.65 & 0.07 & 0.77 \\
\hline $\mathrm{SNF}, \mathrm{kg} / \mathrm{d}$ & 1.84 & 1.75 & 0.07 & 0.41 & 2.33 & 2.28 & 0.09 & 0.69 \\
\hline MUN, mg/dL & 8.1 & 9.3 & 0.54 & 0.11 & 8.8 & 8.7 & 0.54 & 0.96 \\
\hline
\end{tabular}

${ }^{1}$ First $14 \mathrm{~d}$ of the lactation period while on the transition or control diet.

${ }^{2}$ From d 15 to 21 of the lactation period while all cows were on the same lactation diet.

${ }^{3}$ Treatment cows were offered a transition diet in the last $17 \mathrm{~d}$ of gestation and the first $14 \mathrm{~d}$ of lactation, and a lactation diet from d 15 to 21 of lactation.

${ }^{4}$ Control cows were offered a nonlactating cow diet in the last $17 \mathrm{~d}$ of gestation, and a lactation diet in the first 21 DIM. 

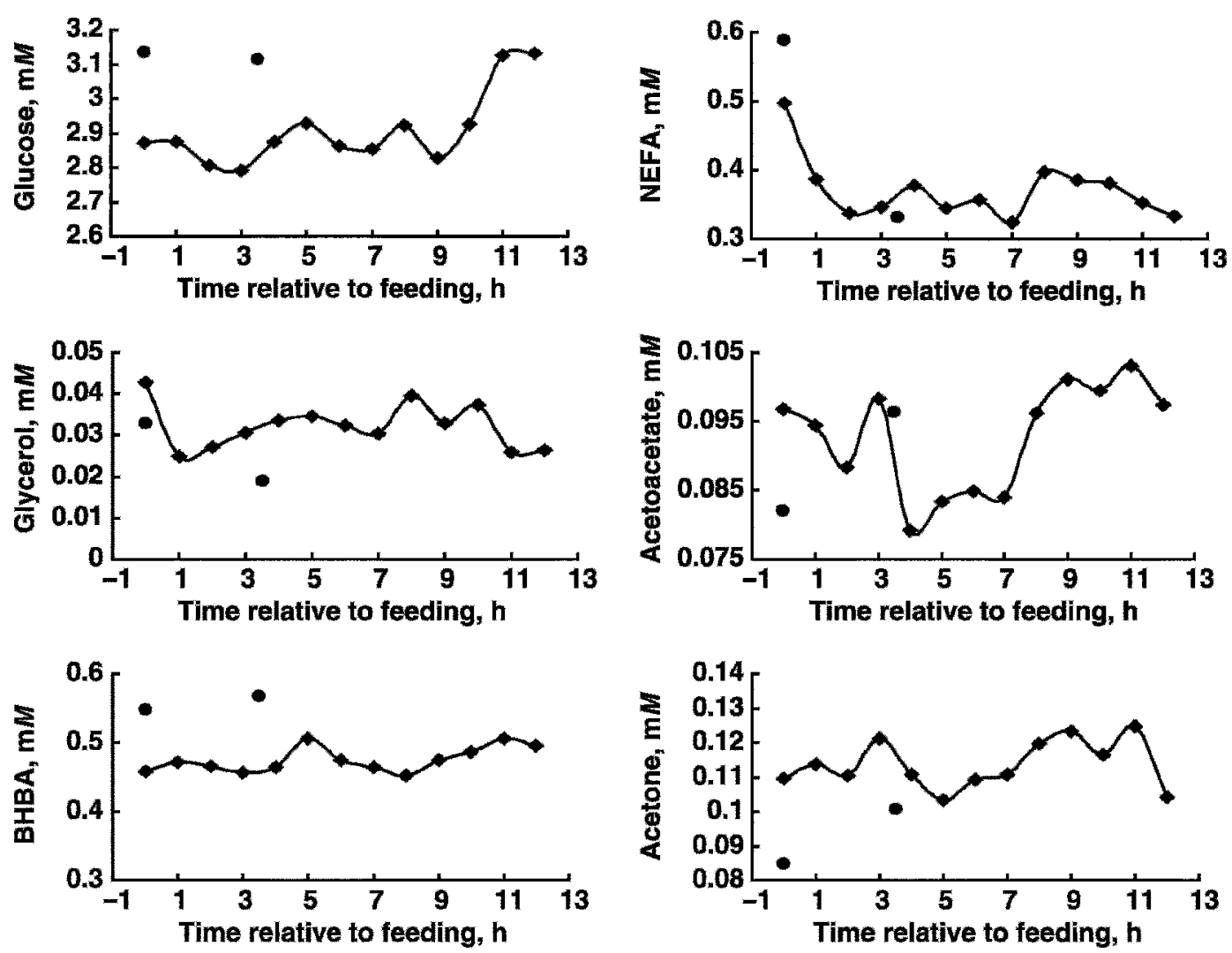

Figure 4. Concentrations of metabolites at each hour throughout a 12 -h period from the jugular vein $(\diamond)$ and at 0 and $3.5 \mathrm{~h}$ after feeding from the coccygeal vein $(-)$ in lactating cows between d 5 and 12 DIM (pooled SEM $=0.13,0.05,0.004,0.029,0.054$, and $0.026 \mathrm{mM}$ for glucose, NEFA, glycerol, acetoacetate, BHBA, and acetone, respectively). The average concentrations of tail samples at 0 and $3.5 \mathrm{~h}$ after feeding were different from those of jugular samples at each hour throughout a 12 -h period for acetoacetate and acetone $(P<0.05)$.

The NEFA concentrations in all cows remained relatively constant in late gestation but began to increase as parturition approached. These concentrations declined for $10 \mathrm{~d}$ after parturition (Figure 5). The average NEFA concentrations in the third week of lactation remained elevated compared with the concentrations before $17 \mathrm{~d}$ relative to calving $(P<0.01)$ in both groups. Cows in the treatment group had greater AUC for NEFA in the third week of lactation compared with the control group $(P=0.004$; Table 5). Changes in plasma glycerol concentrations followed patterns similar to those in NEFA (Figure 5). Feeding the transition diet increased AUC

Table 4. The concentrations of glucose, NEFA, glycerol, acetoacetate, BHBA, and acetone from the jugular and coccygeal veins drawn at the same time ${ }^{1}$

\begin{tabular}{lcccccc}
\hline Item & Acetone & Acetoacetate & BHBA & Glucose & NEFA & Glycerol \\
\hline Jugular, $\mathrm{m} M$ & 0.095 & 0.063 & 0.44 & 2.92 & 0.47 & 0.040 \\
Coccygeal, mM & 0.084 & 0.065 & 0.49 & 3.10 & 0.45 & 0.030 \\
Difference, mM & -0.011 & 0.003 & 0.05 & 0.18 & -0.02 & -0.010 \\
Difference, $\%$ & 12.3 & 4.7 & 10.8 & 6.0 & 4.3 & 28.6 \\
SDD ${ }^{3} \mathrm{~m} M$ & 0.0213 & 0.0370 & 0.220 & 0.812 & 0.156 & 0.0127 \\
UCL, ${ }^{4} \mathrm{~m} M$ & 0.031 & 0.075 & 0.48 & 1.77 & 0.28 & 0.015 \\
LCL ${ }^{5} \mathrm{~m} M$ & -0.053 & -0.070 & -0.38 & -1.41 & -0.32 & -0.035 \\
\hline
\end{tabular}

${ }^{1}$ From 22 cows between 5 and 12 DIM. Blood was drawn before the morning feeding.

${ }^{2}$ Difference calculated as (tail - jugular) $/($ tail $/ 2+$ jugular $/ 2) \times 100 \%$.

${ }^{3}$ Standard deviation of the differences.

${ }^{4}$ Upper confidence limit $=$ mean difference $+1.96 \times$ SDD (Bland and Altman, 1995).

${ }^{5}$ Lower confidence limit $=$ mean difference $-1.96 \times$ SDD $($ Bland and Altman, 1995). 

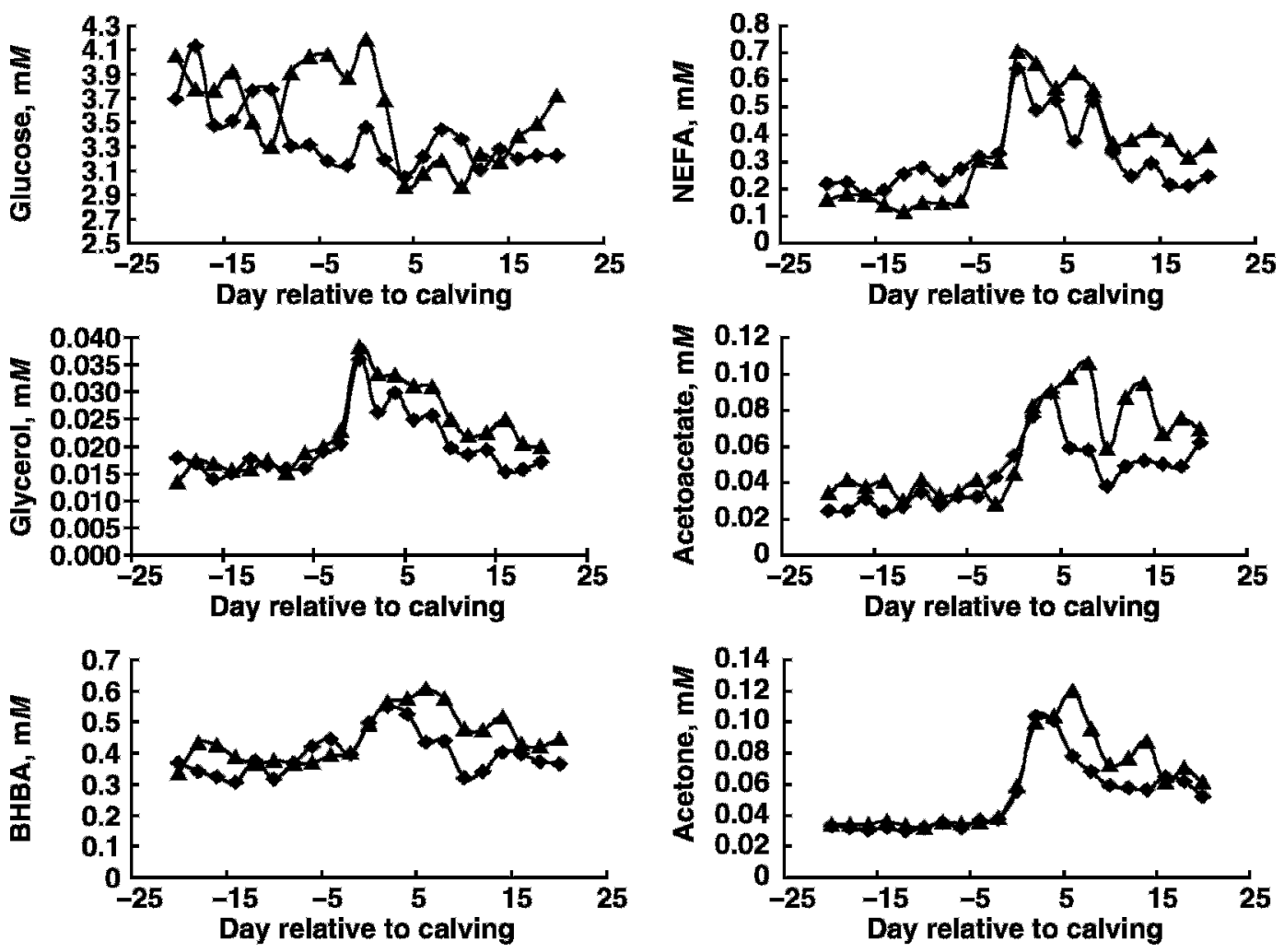

Figure 5. Changes in plasma glucose, NEFA, glycerol, acetoacetate, BHBA, and acetone around the time of calving for cows fed nonlactating and lactation diets prepartum and postpartum (control, $\bullet$ ) or a transition diet from d -17 through d 14 relative to calving (treatment, $\mathbf{\Delta}$ ). Each dot represents the average of 2 contiguous days (pooled SEM $=0.30,0.08,0.004,0.0139,0.071$, and $0.0135 \mathrm{~m} M$ for glucose, NEFA, glycerol, acetoacetate, BHBA, and acetone, respectively). In the last $17 \mathrm{~d}$ of gestation, the area under the curve (AUC) for glucose in the treatment group was greater than that in the control group $(P=0.048)$. In the first $14 \mathrm{~d}$ of lactation, AUC for acetoacetate in the treatment group was greater than that in the control group $(P=0.04)$. Between $d 15$ and 21 postpartum, AUC for acetoacetate, NEFA, and glycerol in the treatment group were greater than those in the control group $(P<0.05)$.

for glycerol across the third week of lactation $(P<0.03$; Table 5). At $d 3$ postpartum, the average concentration of NEFA was $0.8 \mathrm{~m} M$ in the treatment group. With these data, $11.8 \mathrm{~mol}$ of NEFA and $3.9 \mathrm{~mol}$ of glycerol would be predicted to be released from lipid tissue according to the empirical model:

$$
\text { entry rate of fatty acid }=130+0.732 \times \mathrm{NEFA}
$$

$\left(\mathrm{R}^{2}=0.49\right.$; Pullen et al., 1989), where entry rate is the entry rate of fatty acids in $\mathrm{mol} / \mathrm{h}$ per $\mathrm{kg}$ of $\mathrm{BW}$, and NEFA is the plasma concentration (micromolar) of NEFA. Assuming all the glycerol was converted into glucose, approximately $354 \mathrm{~g}$ of glucose could be synthesized from glycerol by gluconeogenesis at d 3 postpartum.

During the periparturient period, plasma concentrations of ACAC followed a pattern similar to those of acetone and BHBA (Figure 5). The treatment group had greater AUC for ACAC than the control group in the first 14 DIM ( $P=0.04$; Table 5$)$ and in the third week of lactation $(P=0.04)$. For all cows, the ratios of ACAC and acetone to BHBA postpartum were greater than those prepartum $(P<0.01)$. The increases in ratios occurred between $5 \mathrm{~d}$ before and after calving (Figure 6 ).

\section{DISCUSSION}

\section{Production Performance}

Cows fed the transition diet in this study were in a more positive energy balance prepartum and a more negative energy balance postpartum compared with control cows. The prepartum difference in energy balance resulted from the greater energy intake in this group. The postpartum difference resulted from the nonsignificantly $(P>0.1)$ greater milk yield and lower energy intake for the treatment group. In practice, cows are transitioned to a high-energy diet immediately after parturition despite whether an intermediate diet is fed (Overton and Waldron, 2004). However, because the transition diet remained the same after parturition in 
Table 5. Effect of a transition diet from $17 \mathrm{~d}$ before calving through 14 DIM on area under the curve (AUC) for different time periods for glucose, NEFA, glycerol, acetoacetate, BHBA, and acetone

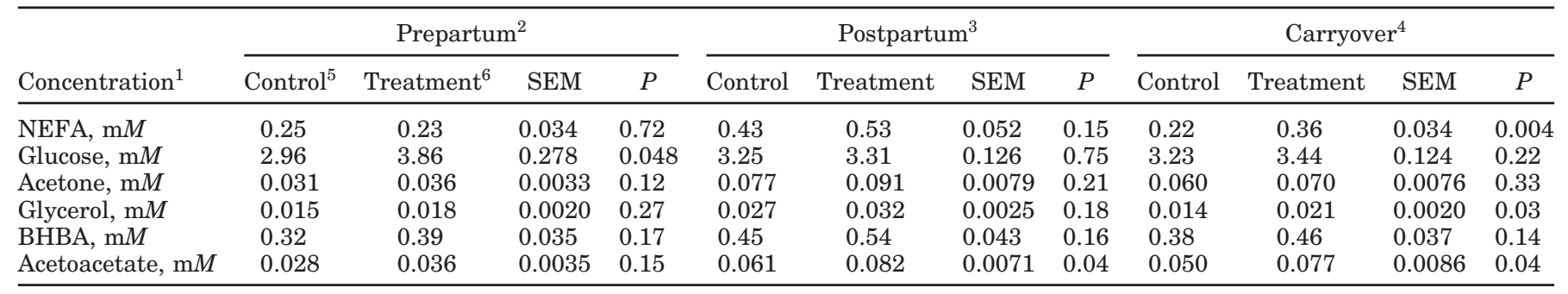

${ }^{1}$ Average concentrations calculated as AUC/d per period.

${ }^{2}$ Last $17 \mathrm{~d}$ of the gestation period.

${ }^{3}$ First $14 \mathrm{~d}$ of the lactation period.

${ }^{4}$ From d 15 to 21 of the lactation period.

${ }^{5}$ Control cows were offered a nonlactating cow diet in the last $17 \mathrm{~d}$ of gestation, and a lactation diet in the first 21 DIM. Number of cows $=$ 14.

${ }^{6}$ Treatment cows were offered a transition diet in the last $17 \mathrm{~d}$ of gestation and the first $14 \mathrm{~d}$ of lactation, and a lactation diet from $\mathrm{d} 15$ to d 21 of lactation. Number of cows $=14$.

this study, the metabolic changes that resulted from parturition alone (treatment) can be compared with the changes that resulted from both parturition and a change in diet (control). Energy balance and DMI were similar for both treatments on the day of parturition, and energy balance was more negative for the transition treatment after parturition. In this study, an abrupt change in diet on the day of parturition appeared to diminish metabolic changes compared with feeding the same intermediate diet throughout lactation.

Feeding a diet high in NSC before calving resulted in increased DMI and energy intake, in agreement with other studies (Minor et al., 1998; Holcomb et al., 2001; Keady et al., 2001; Rabelo et al., 2003). With a high NSC content, ruminal DM digestibility is greater, allowing for faster ruminal absorption and evacuation, and consequently higher DMI, compared with high-forage diets. This would be especially true immediately prior to parturition, when space in the body cavity is limited by the fetus and placenta.

A positive effect on milk yield and milk constituents of increasing dietary energy density precalving had been reported in some studies (Keady et al., 2001; McNamara et al., 2003). However, such an effect had not been observed in other experiments (Mashek and Beede, 2000; Holcomb et al., 2001). Many factors may contribute to the ambiguity of the response, such as variations in cow parity, BCS, basal diet, or the genetic potential of the cows (McNamara et al., 2003). Feeding a highconcentrate diet after parturition increased milk yield (McNamara et al., 2003). The response to postcalving concentrates also depended on the prepartum dietary
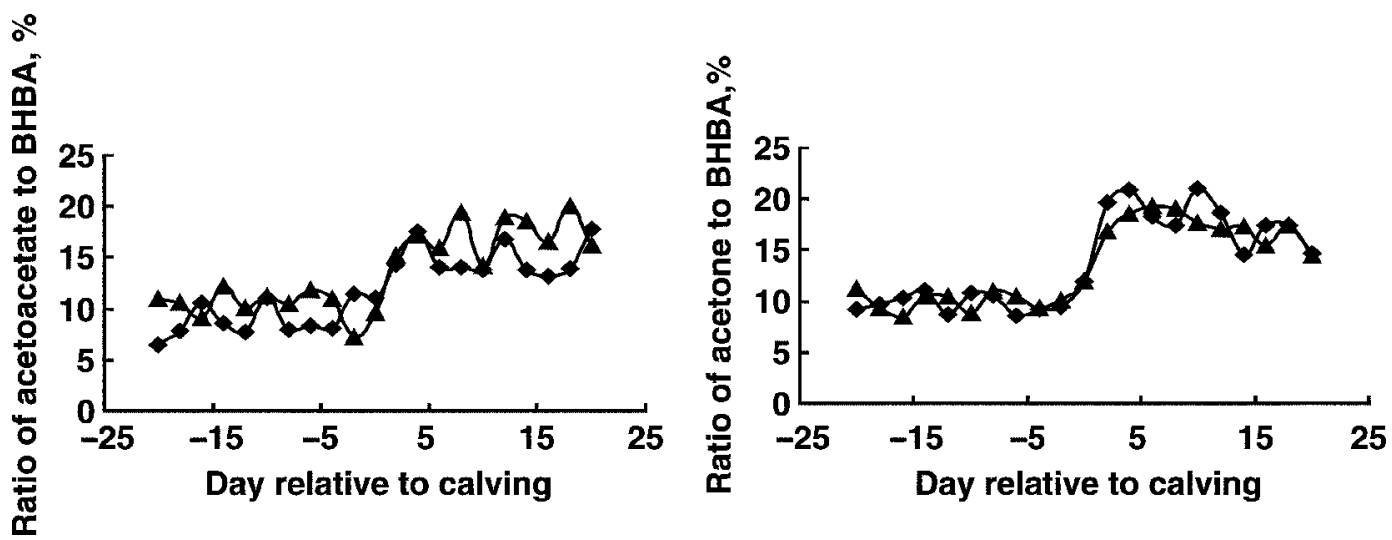

Figure 6. Ratio of plasma acetoacetate to BHBA and acetone to BHBA around the time of calving for cows fed nonlactating and lactation diets prepartum and postpartum (control, $\bullet$ ) or a transition diet from d -17 through 14 relative to calving (treatment, $\mathbf{\Delta})$. Each dot represents the average of 2 contiguous days (pooled $\mathrm{SEM}=3.0$ and 2.5, respectively). For all the cows, the ratios of acetoacetate and acetone to BHBA postpartum were greater than those prepartum $(P<0.01)$. 
energy density (McNamara et al., 2003). In the current study, the treatment cows received a diet with greater energy density precalving and lower energy density postcalving compared with the control cows. Application of the transition diet both before and after parturition may be the reason that no significant effect was detected on milk yield and milk components in the present study.

\section{Blood Samples from the Coccygeal and Jugular Veins}

The average concentration of a blood metabolite across a period of time within a day would be more representative than a single measurement at a specific time point. Blood sampling from the tail vein has become a widely used technique because it produces less disturbance, requires less restraint, and access is easier to obtain compared with jugular vein samples. Thus, the average concentration of blood metabolites from the coccygeal vein at 0 and $3.5 \mathrm{~h}$ after feeding was used in the present study. To justify the representation of blood metabolites, the average concentrations from the coccygeal vein at 0 and $3.5 \mathrm{~h}$ after feeding were compared with the average hourly concentrations across $12 \mathrm{~h}$ in jugular vein samples, with the difference between coccygeal and jugular blood drawn at the same time used as a reference. The difference in blood sampling regimen between the coccygeal and jugular veins was significant only for acetone and ACAC, which may be related to the complicated metabolism in peripheral tissues and to the relatively low energy requirements of the tail.

\section{AUC}

Blood metabolites are highly regulated and coordinated to meet body requirements. However, blood metabolites, especially blood glucose, showed considerable variation after parturition. It was difficult to detect any treatment effect at any specific time point because of the great variation associated with those measurements. In the present study, AUC, which is a measure of exposure to a blood metabolite across a period of time, was used to account for the nonsteady state.

\section{Blood Glucose}

Cows in the treatment group had greater AUC for glucose before parturition than cows in the control group. Rukkwamsuk et al. (1999) reported that highenergy diets increased concentrations of plasma glucose in the last week of gestation. However, Baird et al. (1980) infused propionate in multiparous nonlactating cows and observed no change in blood glucose. The decrease in glucose concentration in the control cows during the last $21 \mathrm{~d}$ of gestation may have resulted from fetal growth and mammary gland development. The increase in glucose concentrations at calving was observed in the present study as well as by Studer et al. (1993). Glucose concentrations at calving are mainly mediated by cortisol and glucagons (Tucker, 1985). Sampling time relative to calving may affect glucose concentration measurements. After calving, glucose concentrations were lower compared with prepartum concentrations in the treatment group, as has been reported previously (Vazquez-Anon et al., 1994; Greenfield et al., 2000). However, this pattern was not observed in the control cows, probably because of the lower glucose availability before parturition or more consistent energy balance as the control group progressed from prepartum to postpartum compared with the treatment group.

\section{Blood NEFA and Glycerol}

The change in NEFA concentrations and the response to the transition diet parallel results from previous studies. Feeding a high-NSC diet lowered NEFA concentrations in the late-gestation period (Minor et al., 1998). As parturition approached, NEFA concentrations increased (Dann et al., 1999), and peaked after parturition. The magnitude of increase in NEFA concentrations after parturition was inversely related to the DMI before parturition (Holtenius et al., 2003). In contrast, McNamara and Hillers (1986) found no effect of dietary energy restriction on the maximal capacity for lipolysis in adipose tissue. The NEFA concentrations in plasma reflect the rate of adipose mobilization (Pullen et al., 1989). In the current study, greater AUC for NEFA in the treatment cows indicated that less adipose tissue was mobilized in the control cows after calving. This decrease in fat catabolism could be explained by the lower energy density in the transition diet compared with the lactation diet. The slightly greater milk yield in the treatment group may be another explanation. Force-feeding cows during the prefresh period only partially reduced the magnitude of NEFA increase postpartum (Bertics et al., 1992). These observations indicated that part of the increase in plasma NEFA was hormonally induced. Cows undergo tremendous endocrine changes during and immediately after calving (Drackley et al., 2001). Most of those changes are also involved in adipose mobilization, such as that mediated by cytokines, catecholamines, estradiol, insulin, and somatotropin (Bell, 1995). In the current study, no dietary effect on plasma NEFA was observed in the first 14 DIM, possibly because the dietary effect was over- 
whelmed by the change in endocrine status. The dietary effect on NEFA was found only in the carryover period (the third week of lactation), perhaps because the effect of the endocrine changes weakened. The carryover effect on NEFA indicated that feeding a transition diet around parturition was associated with greater mobilization of adipose tissue.

The treatment effect on plasma glycerol was also observed in the carryover period, but not in the first 14 DIM, probably for the same reason as for NEFA. Glycerol, as well as NEFA, released into the blood predominantly reflects fat mobilization. The greater AUC for glycerol in the treatment cows indicated that feeding a transition diet around parturition resulted in greater adipose mobilization compared with that of the control cows. It has been widely accepted that fat mobilization in periparturient cows results from a negative energy balance. At d 3 postpartum, the treatment cows were estimated to mobilize approximately $33 \mathrm{Mcal} / \mathrm{d}$ of NEFA from lipid tissue, approximately 4.4 times the calculated negative energy balance of the treatment cows. Bell (1995) estimated that cows at $d 4$ of lactation had a NEFA entry rate of $10.7 \mathrm{~mol} / \mathrm{d}$, which is equivalent to $30 \mathrm{Mcal} / \mathrm{d}$. Any living creature is a self-regulating chemical engine, continually adjusting for maximum economy (Nelson and Cox, 1999). The excessive lipid mobilization could not be caused by negative energy balance per se.

The explanation of why the cows mobilized more fat than needed to meet energy requirements may relate to the characteristics of ruminant glucose metabolism. During the periparturient period, the demand for glucose is increased greatly by fetal growth and milk synthesis, at a time when feed intake is depressed. Glycogen content of the liver remained low in the first 21 DIM compared with the content at $\mathrm{d} 19$ prior to calving (Vazquez-Anon et al., 1994). The increased milk synthesis, depressed DMI, and depletion of liver glycogen suggest that cows could be in a state of glucose deficiency during the periparturient period.

The potential need for glycerol as a glucose precursor has been reviewed (Bell, 1995; Drackley et al., 2001). In the present study, concentrations of glycerol peaked immediately after calving and remained high during the first 21 DIM compared with prepartum concentrations. Measurements of liver pyruvate carboxylase (EC 4.1.1.31) mRNA have indicated an increased gluconeogenesis in the days following parturition (Greenfield et al., 2000). Reynolds et al. (2003) reported that net liver removal of glycerol increased greatly in early lactation. In the current study, the amount of glucose from glycerol via fat mobilization would account for $24 \%$ of milk lactose synthesis at $d 3$ postpartum in the treatment group. This estimate agrees with the report by Bell
(1995) that approximately 15 to $20 \%$ of the glucose demand may be provided by plasma glycerol at d 4 postpartum. The profiles of NEFA and glycerol in the current study indicated that maximum gluconeogenesis from glycerol occurred mainly in the first week of lactation.

The concept that glycerol is a glucose precursor is not new (Lomax and Baird, 1983). However, the contribution of glycerol to gluconeogenesis immediately after calving has not been studied as extensively as that of AA. Although all AA, except Lys and Leu, are also gluconeogenic substrates, Ala and Gln account for 40 to $60 \%$ of the glucogenic potential of all the AA (Bergman and Heitmann, 1978). However, pyruvate may be the ultimate source of the carbon skeleton for Gln and Ala synthesis in vivo (Wolfe, 2001), and a majority of pyruvate is produced by glucose and propionate metabolism in ruminants. In a study by Komaragiri et al. (1998), $12 \mathrm{~kg}$ of body protein was mobilized between -2 and 5 wk postpartum. Bauman and Elliot (1983) concluded that over the period up to peak lactation, the contribution of mobilized tissue protein to gluconeogenesis is small. Glycerol has several advantages over AA for gluconeogenesis. First, periparturient cows are already in negative $\mathrm{N}$ balance, and excessive gluconeogenesis from AA could further exacerbate the protein deficiency. Second, glycerol enters into the metabolic pathway closer to glucose than do glucogenic AA. Third, NEFA and ketone bodies can be used by many peripheral tissues to conserve glucose, whereas excessive ammonia can only be discharged via ureagenesis, which consumes more energy. Finally, the major part of body lipids are stored in adipose tissues and can be mobilized, whereas protein mobilization is attenuated if total protein mobilization exceeds a certain proportion of total body protein mass (Clowes et al., 2003) to prevent excessive depletion. Therefore, the contribution of glycerol from lipolysis may be critical to glucose metabolism during the first week of lactation.

\section{Blood Ketone Bodies}

In the first 21 DIM, cows fed the transition diet had greater AUC for ACAC, and thus were exposed to more ketone bodies and were more susceptible to ketosis compared with control cows. The lower concentrate in the transition diet compared with the lactation diet may account for the larger AUC for ketone bodies in the treatment cows. The increases in ketone body concentrations in this study as well as in others (Greenfield et al., 2000; Dorshorst and Grummer, 2002) are probably related to adipose mobilization and elevated hepatic metabolism when DMI is depressed (Dorshorst and Grummer, 2002). 
In our study, as reported previously (Menaha et al., 1967), the ratio of ACAC to BHBA increased as the total ketone bodies increased. The proportion of ACAC to $\mathrm{BHBA}$ was in equilibrium with the $\mathrm{NAD}: \mathrm{NADH}$ ratio in a reaction catalyzed by BHBA dehydrogenase (EC 1.1.1.30; Williamson et al., 1967). Conversion of NAD to $\mathrm{NADH}$, mediated through glycolysis, may depend on glucose availability in the cytosol. When less glucose is available for glycolysis, less NADH would be generated, which would increase the ratio of ACAC to BHBA. In ketotic cows, the ratio of ACAC to BHBA is high (Heitmann et al., 1987), and NAD:NADH is high in the cytosol. In the present study, the increase in the ACAC:BHBA ratio implies that glucose deficiency developed within $5 \mathrm{~d}$ of parturition, and the cows remained in a negative glucose balance for the remainder of the experiment. This implication is in agreement with the previous observation that hepatic glycogen content, an indicator of carbohydrate status, remained low in the first 21 DIM compared with the content at d 19 prior to calving (Vazquez-Anon et al., 1994).

\section{CONCLUSIONS}

Production performance was not significantly affected by offering a transition diet from 2 wk before parturition to $2 \mathrm{wk}$ after parturition. The positive effects of increased energy density before parturition were offset by the negative effects of lower energy density after parturition. Feeding the transition diet before and after parturition was associated with greater mobilization of adipose tissue and greater exposure to ketone bodies in early lactation, compared with abruptly changing from the nonlactation diet to a peak-lactation diet at parturition.

\section{REFERENCES}

AOAC. 1990. Official Methods of Analysis. 15th ed. Vol. 2. AOAC Int., Arlington, VA.

AOAC. 2000. Official Methods of Analysis. 17th ed. Vol. 2. AOAC Int., Arlington, VA.

Baird, G. D., A. Lomax, H. W. Symonds, and S. R. Shaw. 1980. Net hepatic and splanchnic metabolism of lactate, pyruvate and propionate in dairy cows in vivo in relation to lactation and nutrient supply. Biochem. J. 186:47-57.

Bauman, D. E., and J. M. Elliot. 1983. Control of nutrient partitioning in lactating ruminants. Pages 437-462 in Biochemistry of Lactation. T. B. Mepham, ed. Elsevier, Amsterdam, the Netherlands.

Bell, A. W. 1995. Regulation of organic nutrient metabolism during transition from late pregnancy to early lactation. J. Anim. Sci. 73:2804-2819.

Bergman, E. N., and R. N. Heitmann. 1978. Metabolism of amino acids by the gut, liver, kidneys, and peripheral tissues. Fed. Proc. 37:1228-1232.

Bergmeyer, H. U., J. Bermeyer, and M. Grassl. 1983. Methods of Enzymatic Analysis. 3rd ed. Deerfield Beach, FL.

Bertics, S. J., R. R. Grummer, C. Cadorniga-Valino, and E. E. Stoddard. 1992. Effect of prepartum dry matter intake on liver triglyc- eride concentration and early lactation. J. Dairy Sci. 75:19141922.

Bland, J. M., and D. G. Altman. 1986. Statistical methods for assessing agreement between two methods of clinical measurement. Lancet 1(8476):307-310.

Bland, J. M., and D. G. Altman. 1995. Comparing methods of measurement: Why plotting difference against a standard method is misleading. Lancet 346:1085-1087.

Clowes, E. J., F. X. Aherne, G. R. Foxcroft, and V. E. Baracos. 2003. Selective protein loss in lactating sows is associated with reduced litter growth and ovarian function. J. Anim. Sci. 81:753-764.

Dann, H. M., G. A. Varga, and D. E. Putnam. 1999. Improving energy supply to late gestation and early postpartum dairy cows. J. Dairy Sci. 82:1765-1778.

Dorshorst, M. E., and R. R. Grummer. 2002. Effects of day relative to parturition and dietary crude protein on rumen fermentation in prepartum transition cows. J. Dairy Sci. 85:2290-2298.

Drackley, J. K. 1999. Biology of dairy cows during the transition period: The final frontier? J. Dairy Sci. 82:2259-2273.

Drackley, J. K., T. R. Overton, and G. N. Douglas. 2001. Adaptations of glucose and long-chain fatty acid metabolism in liver of dairy cows during the periparturient period. J. Dairy Sci. 84(E Suppl.):E100-E112.

Edmonson, A. J., I. J. Lean, L. D. Weaver, T. Farver, and G. Webster. 1989. A body condition scoring chart for Holstein dairy cows. J. Dairy Sci. 72:68-78.

Foster, K. J., K. G. Alberti, L. Hinks, B. Lioyd, A. Postle, P. Smythe, D. C. Turnell, and R. Walton. 1978. Blood intermediary metabolite and insulin concentrations after an overnight fast: Reference ranges for adults, and interrelations. Clin. Chem. 24:1568-1572.

Greenfield, R. B., M. J. Cecava, T. R. Johnson, and S. S. Donkin. 2000. Impact of dietary protein amount and rumen undegradability on intake, prepartum liver triglyceride, plasma metabolites and milk production in transition dairy cattle. J. Dairy Sci. 83:703-710.

Harano, Y., K. Kosugi, T. Hyosu, S. Uno, Y. Ichikawa, and Y. Shigeta. 1983. Sensitive and simplified method for the differential determination of serum levels of ketone bodies. Clin. Chim. Acta 134:327-336.

Heitmann, R. N., D. J. Dawes, and S. C. Sensenig. 1987. Hepatic ketogenesis and peripheral ketone body utilization in the ruminant. J. Nutr. 117:1174-1180.

Holcomb, C. S., H. H. Van Horn, H. H. Head, M. B. Hall, and C. J. Wilcox. 2001. Effects of prepartum dry matter intake and forage percentage on postpartum performance of lactating dairy cows. J. Dairy Sci. 84:2051-2058.

Holtenius, K., S. Agenas, C. Delavaud, and Y. Chilliard. 2003. Effects of feeding intensity during the dry period. 2. Metabolic and hormonal responses. J. Dairy Sci. 86:883-891.

Johnson, M. M., and J. P. Peters. 1993. Technical note: An improved method to quantify nonesterified fatty acids in bovine plasma. J. Anim. Sci. 71:753-756.

Jones, N. H. 1997. Finding the Area Under a Curve Using JMP and a Trapezoidal Rule. SAS Inst. Inc., Cary, NC.

Keady, T. W., C. S. Mayne, D. A. Fitzpatrick, and M. A. McCoy. 2001. Effect of concentrate feed level in late gestation on subsequent milk yield, milk composition, and fertility of dairy cows. J. Dairy Sci. 84:1468-1479.

Komaragiri, M. V., D. P. Casper, and R. A. Erdman. 1998. Factors affecting body tissue mobilization in early lactation dairy cows. 2. Effect of dietary fat on mobilization of body fat and protein. J. Dairy Sci. 81:169-175.

Licitra, G., T. M. Hernandez, and P. J. Van Soest. 1996. Standardization of procedures for nitrogen fractionation of ruminant feeds. Anim. Feed Sci. Technol. 57:347-358.

Lomax, M. A., and G. D. Baird. 1983. Blood flow and nutrient exchange across the liver and gut of the dairy cow. Br. J. Nutr. 49:481-496.

Mashek, D. G., and D. K. Beede. 2000. Peripartum responses of dairy cows to partial substitution of corn silage with corn grain in diets fed during the late dry period. J. Dairy Sci. 83:2310-2318. 
McNamara, J. P., and J. K. Hillers. 1986. Regulation of bovine adipose tissue metabolism during lactation. 2. Lipolysis response to milk production and energy intake. J. Dairy Sci. 69:3042-3050.

McNamara, S., F. P. O'Mara, M. Rath, and J. J. Murphy. 2003. Effects of different transition diets on dry matter intake, milk production, and milk composition in dairy cows. J. Dairy Sci. 86:2397-2408.

Menaha, L. A., W. B. Holtmann, L. H. Schultz, and W. G. Hoekstra. 1967. Relationship between $\beta$-hydroxybutyrate and acetoacetate plus acetone contents of blood and urine of the ruminant. J. Dairy Sci. 50:1409-1416.

Mertens, D. R. 2002. Gravimetric determination of amylase-treated neutral detergent fiber in feeds with refluxing in beakers or crucibles: Collaborative study. J. AOAC 85:1217-1240.

Minor, D. J., S. L. Trower, B. D. Strang, R. D. Shaver, and R. R. Grummer. 1998. Effects of nonfiber carbohydrate and niacin on periparturient metabolic status and lactation of dairy cows. J. Diary Sci. 81:189-200.

Nelson, D. L., and M. M. Cox. 1999. Lehninger Principles of Biochemistry. 3rd ed. Worth Publisher, New York, NY

NRC. 2001. Nutrient Requirements of Dairy Cattle, 7th rev. ed. Natl. Acad. Press, Washington, DC.

Overton, T. R., and M. R. Waldron. 2004. Nutritional management of transition dairy cows: Strategies to optimize metabolic health. J. Dairy Sci. 87(E Suppl.):E105-E119.

Pullen, D. L., D. L. Palmquist, and R. S. Emery. 1989. Effect of days of lactation and methionine hydroxy analog on incorporation of plasma fatty acids into plasma triglycerides. J. Dairy Sci. 72:49.

Raabo, E., and T. C. Terkildsen. 1960. On the enzymatic determination of blood glucose. Scand. J. Clin. Lab. Invest. 12:402-407.
Rabelo, E., R. L. Rezende, S. J. Bertics, and R. R. Grummer. 2003. Effects of transition diets varying in dietary energy density on lactation performance and ruminal parameters of dairy cows. J. Dairy Sci. 86:916-925.

Reynolds, C. K., P. C. Aikman, B. Lupoli, D. J. Humphries, and D. E. Beever. 2003. Splanchnic metabolism of dairy cows during the transition from late gestation through early lactation. J. Dairy Sci. 86:1201-1217.

Rukkwamsuk, T., T. Wensing, and M. J. H. Geelen. 1999. Effect of overfeeding during the dry period on the rate of esterification in adipose tissue of dairy cows during the periparturient period. J. Dairy Sci. 82:1164-1169.

SAS Institute. 1999. SAS User's Guide. Statistics, Version 8.0 Edition. SAS Inst., Inc., Cary, NC.

Studer, V. A., R. R. Grummer, and S. J. Bertics. 1993. Effect of prepartum propylene glycol administration on periparturient fatty liver in dairy cows. J. Dairy Sci. 76:2931-2939.

Tucker, H. A. 1985. Endocrine and neural control of the mammary gland. Pages 39-79 in Lactation. B. L. Larson, ed. Iowa State Univ. Press, Ames.

Vazquez-Anon, M., S. Bertics, M. Luck, and R. R. Grummer. 1994. Peripartum liver triglyceride and plasma metabolites in dairy cows. J. Dairy Sci. 77:1521-1528.

Williamson, D. H., P. Lund, and H. A. Krebs. 1967. The redox state of free nicotinamide-adenine dinucleotide in the cytoplasm and mitochondria of rat liver. Biochem. J. 103:514-527.

Wolfe, R. R. 2001. Session II: Physiological aspects of glutamine metabolism I-Discussion summary I. J. Nutr. 131:2496S-2497S. 